\author{
Ana Mikić Čolić1, Ivana Trtanj² \\ 1 Filozofski fakultet Sveučilišta u Osijeku, \\ 2 Fakultet za odgojne i obrazovne znanosti Sveučilišta u Osijeku \\ 1 amikic@ffos.hr, ${ }^{2}$ itrtanj@foozos.hr
}

\title{
O koheziji i koherenciji teksta ${ }^{1}$
}

\begin{abstract}
Ovaj rad donosi sažet pregled teorija koje se bave tekstom, s posebnim naglaskom na pojmove kohezije i koherencije. Naime, tekst je kao potvrda komunikacijske naravi jezika često tijekom jezikoslovne povijesti izmicao gramatičkim opisima. To se mijenja sredinom 20. stoljeća pojavom pravaca aktualne sintakse, sistemske funkcionalne teorije i funkcionalne gramatike M. A. K. Hallidaya te lingvistike teksta. Pojavom tih teorija mijenja se gramatička perspektiva te ona kreće u smjeru od teksta prema rečenici. Premještanje fokusa gramatičkoga opisa na funkcionalne jezične jedinice podrazumijevalo je i intenzivnije zanimanje za (jezičnu) kompetenciju koja se ugrubo raslojava na gramatičku i pragmatičku, odnosno na sposobnost učinkovite uporabe gramatičkoga znanja. Važan aspekt te učinkovite jezične uporabe u svim teorijskim pristupima čine upravo kohezija - prisutnost izravnih jezičnih veza koje omogućuju stvaranje strukture u tekstu - i koherencija - stupanj smislenosti teksta. Cilj je ovoga rada istražiti i donijeti pregled dijela teorijskih pristupa koji su se bavili tim dvama složenim pojmovima prije svega zato što njihovih sustavnih opisa gotovo da i nema u kroatistici.
\end{abstract}

\section{Uvod}

Kompetencija se leksikografski određuje kao 'sposobnost kojom tko raspolaže' (Anić 1998: 423), a koja može biti urođena ili se može razvijati učenjem. Taj je pojam u jezikoslovlje uveo Noam Chomsky sredinom 20. stoljeća tumačeći da svaki govornik posjeduje apstraktnu jezičnu sposobnost ili kompetenciju (engl. competence) koja je razdvojena od uporabe (engl. performance). Vrlo brzo Chomskyjevo tumačenje jezične sposobnosti kao apstraktnoga koncepta doživjelo je kritike ponajprije jer je iz njezina tumačenja potpuno isključio sociološke i psihološke aspekte posjedovanja jezičnoga znanja. Stavljanjem u središte lingvističke pozornosti govornika koji na kraju svoga jezičnog razvoja ne posjeduje samo gramatičko znanje, nego i znanje o njegovoj prikladnoj uporabi u određenom komunikacijskom i širem kulturnom kontekstu, rezultiralo je pojmom komunikacijske kompetencije za koji

1 Ovaj je rad sufinancirala Hrvatska zaklada za znanost (IP-2016-06-5736). 
je zaslužan Dell H. Hymes. Tako shvaćena komunikacijska kompetencija sastoji se od gramatičke kompetencije koja podrazumijeva poznavanje gramatičkih pravila i uporabne kompetencije, koja se pak odnosi na poznavanje pravila o uporabi jezika (Hymes 1972). Otada se pojmovi jezične i komunikacijske kompetencije u lingvističkim teorijama isprepliću, a u različitim tumačenjima vrlo često dolazi i do preklapanja pojmova jezične i gramatičke kompetencije. Detaljniji pogled u različite koncepte gramatičke kompetencije otkriva činjenicu da su fonološka, morfološka, sintaktička i leksička komponenta prisutne u svim modelima gramatičke kompetencije, dok se samo neki proširuju i aspektima diskursne te pragmatičke kompetencije. Bachman (1990), Bachman i Palmer $(1996,2010)$ te Pavičić Takač i Bagarić Medve (2013) diskursnu i pragmatičku kompetenciju odvajaju od gramatičke kompetencije, a sve tri spomenute kompetencije objedinjuju pod pojmom jezične kompetencije. Budući da je predmet ovoga rada tekst, odnosno elementi koji skup rečenica čine tekstom, pozornost će se u nastavku posvetiti isključivo diskursnoj kompetenciji.

Cilj je ovoga rada istražiti i donijeti pregled dijela teorijskih pristupa koji su se bavili tekstom, odnosno sastavnicama diskursne kompetencije, ili konkretnije, onim elementima koji tekst čine tekstom - s posebnim naglaskom na koheziju i koherenciju - prije svega zato što njihovih sustavnih opisa gotovo da i nema u kroatistici. U radu se predstavljaju i rezultati istraživanja kohezije i koherencije teksta inojezičnih govornika hrvatskoga kojima će se, iz inojezične perspektive, nastojati potkrijepiti teorijske postavke o tim dvama konceptima.

\section{2. Što tekst čini tekstom: o diskursnoj kompetenciji}

U raspravama o gramatičkoj kompetenciji s jedne, te pragmatičkoj s druge strane, iz vida se često gubi činjenica da je jednako važno i znanje koje svakom govorniku omogućuje povezivanje jezičnih elemenata nižega reda (riječi, rečenica) u cjeloviti i smisleni pisani ili usmeni tekst. Termin diskurs prvi je 1952. u knjizi Discourse analysis upotrijebio Zellig Harris. Ulingvističkoj koncepciji diskurs je najčešće shvaćen kao jezična uporaba, odnosno jezik u uporabi (McHoul 1994). Uporaba jezika nije ograničena na govor, većse, ističe van Dijk (1997), uključuje u pisani jezik i kada čitamo novine, knjigu, e-poštu ili bilo koju drugu vrstu pisanoga teksta. Bez obzira na to svrstavamo li diskursnu analizu u višu razinu strukture jezika od morfologije i sintakse ili u posebnu perspektivu većih jezičnih jedinica koje imaju utjecaj na manje jedinice u jezičnom sustavu, npr. riječi i rečenice, analizom diskursa istražujemo uporabu jezika u kontekstu. Diskursna analiza usmjerena je na jezičnu uporabu koja je potaknuta pravim komunikacijskim potrebama i na jezik s pomoću kojega uspijevamo ostvariti različite događaje i međudjelovanja (He 2001). To se znanje naziva diskursnom kompetencijom, a najčešće se određuje kao poznavanje načina za povezivanje i tumačenje jezičnih oblika i značenja radi postizanja smislene cjelovitosti govornih ili pisanih tekstova različitih žanrova (Canale 1983). S obzirom na (ne) 
razlikovnost pojmova diskurs i tekst ${ }^{2}$ uz pojam diskursne kompetencije javlja se, kao jednakovrijedan, i pojam tekstne kompetencije, koji podrazumijeva sposobnost razumijevanja i proizvodnje tekstova, odnosno poznavanje konvencija za povezivanje rečenica ili iskaza u tekst (Bachman 1990; Bachman i Palmer 1996; 2010). Određenje diskursne kompetencije donosi i Zajednički europski referentni okvir za jezike ${ }^{3}$ (2005) prema kojemu je ona određena kao sposobnost učenika i korisnika jezika da niže rečenice kako bi proizveo koherentne jezične cjeline. U sastavnice diskursne kompetencije u ZEROJ-u ubrajaju se: poznavanje i sposobnost upravljanja rasporedom rečenica u pisanome i usmenome diskursu prema temama/glavnim mislima, sposobnost strukturiranja diskursa i upravljanja njime prema tematskoj organizaciji, djelatnosti i povezanosti, logičnom rasporedu, stilu i registru te retoričkoj učinkovitosti te poznavanje konvencija za planiranje teksta u određenoj zajednici.

Svoj pristup diskursnoj kompetenciji Savignon (1983) temelji na činjenici da uspješnost povezivanja rečenica i izričaja u smislenu cjelinu ne ovisi samo o jezičnom znanju te znanju o diskursnim strukturama, nego i o drugim znanjima koja dijele svi sudionici u komunikaciji, a koja se mogu odrediti kao znanja o svijetu te društvenom okruženju. U slučajevima kada se značenje ne može izvesti iz rečenica, u njihovu »dešifriranju " oslanjamo se upravo na ta znanja čime je Savignon u odnos međuovisnosti stavila diskursnu kompetenciju i znanje o svijetu4. Yule (1996) također primjećuje interakciju diskursne kompetencije i znanja o svijetu te tvrdi da sudionici komunikacijskoga čina bez problema razumijevaju i one poruke u kojima veći dio onoga što se mislilo nije izgovoreno riječima. Govornici daju smisao onome što čuju ili čitaju, odnosno pokušavaju povezati interpretaciju teksta sa svojim vlastitim iskustvom u svijetu oko sebe. Primjerice, u tekstu koji donosi Widdowson (1978) ne postoji kohezivna veza koja pretvara ove tri rečenice u smislenu cjelinu:

(1) Ona: Telefon!

On: U kupaonici sam.

Ona: Uredu.

Yule (1996) se pita kako je svaki od to dvoje ljudi uspio shvatiti što drugi kaže? Tvrdi da nam je za obavijest o toj rečenici potrebno pragmatičko znanje (znanje o

2 Velčić (1987: 11) termin diskurs pripisuje anglosaksonskoj, francuskoj i američkoj lingvističkoj tradiciji, termin tekst ruskoj i američkoj, a termin nadrečenično jedinstvo uglavnom ruskoj tradiciji. Treba napomenuti i da se tekst često izjednačava s diskursom. Neke teorije tekst smatraju manje ili više proizvodom, rezultatom diskursa koji sam po sebi dovodi do stvaranja teksta. Tekst se određuje i preko svoje prepoznatljive svrhe, što pri takvu tumačenju dovodi do raščlanjivanja tekstova na brojne funkcionalne vrste kojima se pridružuju određene jezične značajke. Tekst se, nadalje, u nekim teorijama smatra apstrakcijom, a diskurs njegovim ostvarenjem. Također, neki jezikoslovci jednostavno misle da je tekst ono što je napisano, a diskurs ono što je izgovoreno. Svim se terminima, smatra Velčić (1987), upućuje na jednako bitna obilježja jedinice više razine: jedinstvenost, cijelost i povezanost.

3 Budući da će se u radu govoriti i o koheziji i koherenciji teksta inojezičnih govornika hrvatskoga, smatramo relevantnim, osim znanstvenih pristupa diskursnoj kompetenciji, i njezino određenje u Zajedničkom europskom referentnom okviru za jezike (dalje u tekstu ZEROJ).

4 Žic Fuchs (1991) definira znanje o svijetu ili konceptualnu strukturu kao mentalno procesuiranje svega što nas okružuje, svega što percipiramo i doživljavamo. 
govornim činovima: postavljanje namjere, iznošenje namjere, izvršenje namjere) jer obavijest sadržana u rečenicama nije dovoljna za pronalaženje smisla. Jasno je, zaključuje Yule, da konverzacijska interakcija nije samo gramatičko i semantičko znanje, već i pragmatičko znanje, u kognitivnoj lingvistici poznato kao već spomenuto znanje o svijetu. Nadalje, Yule (1996) pojmom shema naglašava važnost spoznajne obrade i djelovanja radnoga pamćenja na diskurs i događaje koji nas okružuju. Svaki čovjek u svom umu posjeduje bezbroj shema koje upotrebljava u interpretaciji onoga što u danom trenutku doživljava.

U svojem tumačenju komunikacijske kompetencije Celce-Murcia (2007) raspravlja o govornim činovima. Naime, autorica u svoj model uvodi interakcijsku kompetenciju koju smatra protutežom sociokulturnoj kompetenciji, određenoj kao pragmatičko znanje, odnosno znanje o tome kako svoj izričaj učiniti prikladnim društvenom i kulturnom kontekstu u kojem se komunikacija odvija. To se znanje upotpunjuje znanjima koja obuhvaća interakcijska kompetencija, a to je način kojim se jezičnim sredstvima oblikuju govorni činovi, način na koji se vodi konverzaciju te način na koji se koriste neverbalna, odnosno paralingvistička sredstva u komunikaciji.

Kao što je razvidno iz određenja diskursne kompetencije, u središtu je pozornosti svih pristupa tekst.

U jezikoslovnoj je kroatistici Josip Silić još 1984. postavio temelje za istraživanja o tekstu i diskursu svojom knjigom Od rečenice do teksta: Teoretsko-metodološke pretpostavke nadrečeničnog jedinstva. Kako sam autor kaže, cilj mu je bio "prikazati povezanost rečenice $s$ rečenicom u nadrečeničnom jedinstvu i koliko aktualno raščlanjivanje rečenice (raščlanjivanje rečenice na 'smisaoni' subjekt - obavijesni subjekt, dato, temu i na 'smisaoni predikat' - obavijesni predikat, novo, remu) utječe na povezanost rečenice s rečenicom u nadrečeničnom jedinstvu« (1984: 7).

Apstraktna jezična kompetencija govornika koju smo spomenuli na početku uvodnoga poglavlja nije podrazumijevala jezičnu uporabu te je u skladu s tim tekst kao osnovna jedinica jezičnog sustava, osnovna informacijska i komunikacijska jedinica te osnovna jedinica jezičnoga djelovanja (Glovacki-Bernardi 2004: 5) često izmicao sustavnim lingvističkim opisima. To se mijenja pojavom triju lingvističkih pravaca koji upravo tekst stavljaju u središte pozornosti: aktualna sintaksa, sistemska funkcionalna teorija M. A. K. Hallidaya te lingvistika teksta (Badurina 2007; 2011; 2016). Sva tri pravca počinju uzimati u obzir komunikacijsku funkciju jezika, što je automatski podrazumijevalo premještanje središta interesa s jedinica nižih razina jezičnoga opisa (fonem, morfem, leksem, rečenica) na tekst, koji se počinje određivati kao »sve ono što nastaje jezičnim djelovanjem, što jezična kreativnost govornika pretvara u uobličeni jezik« (Glovacki-Bernardi 2004: 19). Dakle, moguće je razaznati dva pravca određivanja pojma tekst: prvi je strukturalistički, odnosno generativno-transformacijski, koji tekst određuje kao jedinicu jezika kojoj je osnovna značajka da se sastoji od koherentnoga slijeda rečenica, pri čemu se pojam koherentnosti shvaća isključivo gramatički - kao sintaktičko-semantički odnos među 
rečenicama ili među jezičnim elementima u uzastopnim rečenicama. Drugo je tumačenje teksta pragmalingvističko ili komunikacijsko, pri čemu se tekst shvaća kao djelovanje, kao konkretizacija jezika (Glovacki-Bernardi 2004). U obama pristupima tekst pretpostavlja pojam strukture, a sastavnice koje toj strukturi doprinose jesu: kohezija, koherencija, intencionalnost, prihvatljivost, informativnost, situativnost i intertekstualnost (de Beaugrande i Dressler 1981). Kohezija i koherencija usmjerene su na tekst, dok je preostalih pet konstitutivnih načela teksta usmjereno na sudionike komunikacijskoga čina. Intencionalnost tako podrazumijeva govornika i njegovu namjeru da tekst bude koherentno organiziran te da se njime postigne odgovarajući komunikacijski čin, dok prihvatljivost fokus stavlja na recipijenta i njegovu spremnost i sposobnost da u slijedu pojavnosti prepozna kohezivan i koherentan tekst te da ga prihvati kao komunikacijski relevantnu činjenicu. Informativnost se odnosi na izmjenu očekivanih i neočekivanih elemenata unutar teksta, dok situativnost upućuje na uvjetovanost teksta situacijom u kojoj se pojavljuje ili, drugim riječima, svjedoči o prilagođenosti teksta izvanjezičnom kontekstu. Naposljetku, intertekstualnost se potvrđuje u ovisnosti teksta o drugim, prethodno realiziranim tekstovima, odnosno razumijevanje jednoga teksta ovisi o poznavanju jednoga ili više već poznatih tekstova (Badurina 2011).

Yule (1996) također tvrdi da tekst mora imati određenu strukturu koja ovisi o raznim čimbenicima, koji su poprilično drukčiji od onih koji su zahtijevani u strukturijedne rečenice. Među ključne čimbenike koji utječu na strukturu teksta također ubraja intencionalnost, informativnost te koheziju i koherenciju. Dakle, u tekstu je moguće uočiti leksičko-gramatička sredstva koja na sebe preuzimaju ulogu povezivanja različitih formalnih dijelova cjeline - u tom slučaju govorimo o koheziji - no s druge strane treba imati na umu da se povezivanje ne može svesti isključivo na formalna jezična sredstva jer u nekim oblicima komuniciranja takvih sredstava nema (npr. upute za pripremu jela, oglasi), a opet ih poimamo kao smisaone cjeline - u tom kontekstu govorimo o koherenciji (Velčić 1987). Mehanizam povezivanja zahvaća sve razine iskaza i ne očituje se samo na njegovoj formalnojezičnoj strani. Zbog svoje složenosti, ali i zbog neizostavne uloge kada su teorije i određenja teksta u pitanju, upravo koheziji i koherenciji bit će posvećena veća pozornost u poglavljimakoja slijede.

\subsection{Kohezija}

U analizi kohezije (i koherencije) ponovno ćemo krenuti od leksikografskih određenja. Kohezija se tako određuje kao 'veza, povezanost slijeda misli', dok za koherenciju stoji 'sveza, spojenost, sraslost, povezanost' (Anić, Klaić, Domović 2002: 701). Upravo u sličnim rječničkim definicijama treba tražiti uzroke miješanju tih dvaju pojmova, no kada je riječ o tekstu, odnosno diskursu, kohezija i koherencija odnose se na vidno drukčije aspekte njihove strukturiranosti.

Kohezija teksta očituje se u vezama među rečenicama/iskazima i ostvaruje se kohezivnim sredstvima (Halliday, Hasan 1976). Dakle, Halliday i Hasan (1976) 
smatraju da primarna odrednica toga hoće li skup rečenica činiti ili neće činiti tekst ovisi o kohezivnoj vezi, unutar i među rečenicama koja stvara teksturu. Specifičnost je njihova tumačenja kohezije što smatraju da je upravo ona presudna za tumačenje značenja teksta. ${ }^{5}$ Tekst ima teksturu i to je ono što ga razlikuje, tvrde ti autori, od nečega što nije tekst.

Prema Hallidayu (1975) koncept kohezije određen je unutarnjim odnosima koji oblikuju tekst te on, u skladu s tim, nudi sljedeću podjelu kohezivnih sredstava:

1. gramatička kohezija:

a. strukturalna: zavisnost (subordinacija) i povezivanje (koordinacija)

b. nestrukturalna: anafore i supstitucije

2. leksička kohezija:

a. ponavljanja

b. pojava jedinica istoga leksičkog skupa.

U svom pristupu strukturi teksta Halliday (1975) razlikuje ove vrste kohezije: referencijalnu koheziju (egzofore i endofore, anafore i katafore) supstitutivnu i eliptičnu koheziju, konjunktivnu (vezničku/konektorsku) koheziju te leksičku koheziju. Referencijalnu koheziju Halliday prepoznaje u onim elementima jezičnoga sustava koji su objašnjivi isključivo ako ne upućuju samo na sebe, već na nešto drugo. Takva su jezična sredstva osobne i pokazne zamjenice te komparativi, npr. on, to, kasnije. Navedene su referencije potpuno razumljive i same po sebi, ali objašnjive su tek ako znamo tko je on, što je to te u odnosu na što je kasnije. Referencije, dakako, mogu biti egzofore i endofore te anafore i katafore. Egzoforička uporaba pretpostavlja upravo to da se pomoću zamjenica upućuje na nešto u izvanjezičnoj stvarnosti, tj. da se one javljaju u deiktičkoj funkciji.

Sustavno se tekstom, odnosno suprasintaksom, u hrvatskoj lingvistici bavi Badurina (2011) koja se priklanja tumačenju kohezije (prema Beaugrande i Dressler 1981) kao načina na koje su komponente površinske strukture teksta, tj. riječi koje vidimo i čujemo međusobno povezane u slijedu, pri čemu te površinske komponente ovise jedna o drugoj u skladu s gramatičkim obrascima i konvencijama te se može tvrditi da kohezija počiva na gramatičkim ovisnostima. Drugim riječima, ona se očituje u vezama među rečenicama, odnosno iskazima unutar teksta, a ostvaruje se gramatičkim i semantičkim sredstvima (tzv. kohezivnim sredstvima - zamjenicama, glagolskim vremenima, leksičkim vezama, ponavljanjima rečeničnih struktura, komparacijama i supstitucijama, elipsama, rečeničnim veznicima, odnosno konektorima itd.).

Na tom su tragu i Watson Todd, Thienpermpool i Keyuravong (2004: 87), koji koheziju određuju kao površinsku vezu među tekstnim jedinicama i tvrde da je moguće uočiti elemente u tekstu koji osiguravaju kohezivnost, što ju čini »relativno objektivnom « tekstnom vrijednosti. Pavlou (1994) također tvrdi da se kohezija od-

»The concept of cohesion is a semantic one: it refers to relations within the text! (Halliday, Hasan: 1976: 4). 
nosi na površinsku strukturu teksta te napominje da kada istražujemo koheziju, zapravo istražujemo na koji način, odnosno koje (jezične) jedinice omogućuju da tekst funkcionira kao jedna značenjska cjelina/jedinica. Palmer (1999) navodi da se kohezija temelji na sintaksi i na leksiku. Da je riječ o površinskoj strukturiranosti tvrdi i Glovacki-Bernardi (2004) govoreći o asertoričkoj koheziji koja podrazumijeva povezivanje rečenica ili većih cjelina pomoću veznika ili čestica, npr. doista, ali te o foričkim sredstvima, odnosno o povezivanju elemenata u tekstu, i semantičkih i sintaktičkih, na način da se elementi teksta povezuju s elementima koji im prethode ili s elementima koji dolaze poslije njih. S obzirom na smjer povezivanja Glovacki-Bernardi (2004) razlikuje:

a) anaforičke elemente (povezivanje unatrag, tj. elementi se nadovezuju na one koji im prethode; veznici, zamjenice)

b) kataforičke elemente (povezivanje unaprijed, elementi se nadovezuju na one koji će uslijediti; veznici).

Kada je riječ o kohezivnoj strukturi teksta, upravo se forički elementi određuju kao primarni (Badurina 2011) te se u nastavku donosi pregled njihova tumačenja.

Anafora se najčešće definira kao lingvistički element koji se tumači na temelju drugog elementa u istoj rečenici ili diskursu. »Anaforički se odnosi najčešće ostvaruju supstitucijom, imenovanjem istoga referenta na različite načine te tu ulogu mogu imati veznici, čestice, prilozi i zamjenice." (Kuna 2008: 200) Anafora pritom može biti jedna riječ, skupina riječi, može se nalaziti u istoj rečenici u kojoj se nalazi i njezin antecedent, ali i ne mora. Potvrda opisanih situacija jesu sljedeći primjeri.

(2) Tena želi pronaći posao u Parizu, ali ona prije toga mora naučiti francuski.

U navedenom primjeru osobna zamjenica ona je anafora, a vlastita imenica Tena njezin je antecedent. Odnos je između tih dvaju elemenata anaforičan ili vezujući jer je ona vezano za Tena.

(3) Lovro se ozlijedio.

U primjeru (3) anafora je povratna zamjenica se, a njezin je antecedent imenica Lovro. Anafora može biti i skupina riječi kao u sljedećem primjeru:

(4) Tena i Lovro često viđaju jedno drugo.

Na početku je spomenuto da antecedent anafore ne mora stajati u istoj rečenici kao i anafora. U primjeru:

(5) Tena izgleda iscrpljeno. Mislim da joj treba odmor.

antecedent Tena ne nalazi se u istoj rečenici kao i anafora joj koja upućuje na taj antecedent. 
Prvo i osnovno svojstvo povezivanja elemenata u tekstu, semantički i sintaktički, vrlo je jednostavno - elementi, odnosno sastavnice teksta povezuju se ili s elementima koji im prethode, ili s elementima koji stoje iza njih. To međuupućivanje u tekstu Silić i Pranjković nazivaju foričnošću rečenice (2005: 359) te na primjerima koji slijede također utvrđuju da ona može biti dvosmjerna:

(6) Svi smo otišli na more. Ondje smo se dobro odmorili.

U navedenom primjeru anaforični element ondje iz druge rečenice upućuje na element na more iz prve rečenice i time povezuje te dvije rečenice.

Ako, tumače Silić i Pranjković (2005: 359), rečenica nekom svojom sastavnicom upućuje na element rečenice koji slijedi iza rečenice s takvim elementom ili na tu rečenicu u cjelini, onda je riječ o kataforičnosti kao u sljedećem njihovu primjeru:

(7) Na moru smo različito reagirali. Jedni su bili zadovoljni, a drugi nezadovoljni.

Element različito iz prve rečenice kataforičke je naravi. On upućuje na elemente jedni, odnosno drugi u sljedećoj rečenici i time te dvije rečenice povezuje u jednu tekstnu cjelinu.

Signale tekstne uključenosti rečenice Silić i Pranjković (2005) nazivaju konektorima. Konektori su vezna sredstva na razini teksta. Njima se pojedine rečenice (jednostavne ili složene) povezuju u cjelinu koja čini tekst. S obzirom na smjer povezivanja u tekstu, odnosno s obzirom na smjer povezivanja s kontekstom, svi konektori imaju foričku, odnosno anaforičku ili kataforičku funkciju. U nastavku rada donosimo pregled anaforičkih odnosa na konkretnim primjerima, a s obzirom na navedene vrste anaforičkih elemenata.

Funkciju usmjeravanja pozornosti recipijenta na ono što će uslijediti često vrše zamjenice koje upućuju na nešto što je prethodilo u tekstu, dakle, usmjerene su unatrag.

Opisanu situaciju oslikavaju sljedeći primjeri:

(8) Ljudi su počeli pjevati pjesmu koju je u sebi pjevušila i ona.

(9) Ona se boji profesorice od koje svi strepe.

U primjerima (8) i (9), osim već označenih anafora unutar rečenice, izdvaja se osobna zamjenica ona koja se također, ali sada na iznadrečeničnoj razini, može označiti kao anafora. Naime, i u jednoj i u drugoj rečenici osobna zamjenica ona anafora je antecedentima koji se nalaze u prethodnim rečenicama.

U primjeru koji slijedi također je riječ o anafori čiji se antecedent nalazi u prethodnoj rečenici pa on ovdje ima funkciju tekstnoga konektora.

(10) Bio je neki mali postolarski šegrt. On nije imao ni oca ni majku.

Kada je riječ o zamjenicama, posebno treba izdvojiti povratno-posvojnu zamjenicu svoj. Ona, naime, »nema vlastitu referenciju, već samo upućuje na neku 
drugu rečeničnu sastavnicu, upućuje na drugu imeničnu skupinu - na svoj antecedent te je o njemu sintaktički i semantički ovisna« (Kuna 2008).

(11) Tena i Lovro izišli su iz moje nove kuće.

(11a) Tena i Lovro izišli su iz svoje nove kuće.

Odnos anafore (zamjenice) i njezina antecedenta predmet je brojnih radova koji su nastali u okviru nekih od modula generativne gramatike. Sam Chomsky definirao je nekoliko prilično različitih teorija unutar generativnoga pristupa gramatici. Za temu ovoga rada posebno je zanimljiva teorija vezanja koja se bavi anaforičkim odnosima. Ona drugim riječima opisuje interpretativne odnose među različitim imenskim skupinama u rečenici, odnosno nužne ili moguće anaforičke odnose među njima, određuje razdiobu povratnih i nepovratnih zamjenica, a ima i važnu ulogu u određivanju razdiobe praznih kategorija. »U teoriji vezanja ključno je imaju li dvije kategorije isti ili različit indeks. Ako imaju isti indeks, to znači da dijele neka zajednička obilježja. Pridruživanjem se indeksa može odrediti je li neka rečenica pravilno sastavljena ili nije.«(Kuna 2008: 200)

(12) ${ }^{*}$ Buga $_{\mathrm{i}} \mathrm{ju}_{\mathrm{j}}$ je vidjela.

(13) Buga ${ }_{\mathrm{i}}$ želi da ju $\mathrm{J}_{\mathrm{i}} \mathrm{Jakov}_{\mathrm{i}}$ posluša.

(14) Buga ${ }_{i}$ se $_{i}$ ošišala.

(15) ${ }^{*}$ Buga $_{i}$ želi da se Jakov $_{j}$ ošiša.

Promotre li se anafore (u svim navedenim primjerima riječ je o zamjenicama) i njihovi antecedenti dolazi se do sljedećih zaključaka: primjer (12) nije pravilno sastavljen ako imenske skupine Buga i ju imaju isti indeks, odnosno ako se odnose na istu osobu, dok je primjer (13) pravilno sastavljen. Primjer (14) također je pravilno sastavljen, dok struktura pod brojem (15) nije jer je antecedent povratnoj zamjenici se u tom primjeru Jakov, a ne Buga kako je to označeno indeksima. Razlog je različitom gramatičkom položaju struktura (12) i (15) upotreba povratne zamjenice se u primjeru (15), odnosno upotreba nepovratne zamjenice ju u primjeru (12). Očito je da ne vrijede za sve tipove imenskih skupina ista pravila o mogućnosti anaforičkoga odnosa s drugim imenskim skupinama (Mihaljević 1998). Povratne se zamjenice od osobnih i drugih nepovratnih zamjenica razlikuju ne samo time što moraju imati antecedent, već i time da antecedent mora biti u istoj sintaktičkoj domeni s njima. Osobne zamjenice ne moraju imati lingvistički izražen antecedent, a ako ga imaju, on u načelu može biti u istoj surečenici s njima. To znači da su povratne i nepovratne zamjenice obično komplementarno razdijeljene. Gdje se može pojaviti jedna vrsta, ne može se pojaviti druga i obrnuto.

Glovacki-Bernardi (2004) već spomenuto sintagmatsko supstituiranje, odnosno anaforičku funkciju, ističe kao najvažniju kada je riječ o zamjenicama. Osim što im je značenje od velike važnosti kada je riječ o anafori, značenje je zamjenica neupitno kada je u pitanju konstituiranje teksta, ali i funkcioniranje jezika uopće. Pođe li se od činjenice da je jezik jedan od glavnih oblika ljudskoga djelovanja, onda 
onaj tko djeluje jezikom, govornik ili pisac, stoji u prvom planu s pragmatičkoga stajališta. Osim toga, jezik je vezan za zajedničko, koncentrirano ponašanje, govornik neprestano mora uzimati u obzir i svoje slušatelje, odnosno čitatelje. Govornik i slušatelj na taj način zauzimaju krajnja mjesta u perspektivi jezičnoga djelovanja. Tome u samom jeziku odgovara ta vrlo ograničena vrsta riječi, koja doista odgovara realnim kategorijama govornika i slušatelja (Glovacki-Bernardi 2004).

Posebnu grupu konektora, s obzirom na njihovu foričku funkciju, tvore oni koji istodobno imaju i anaforičko i kataforičko značenje, a to su veznici:

(16) Vrijeme za pisanje ispita državne mature gotovo je isteklo. Ali svi su još pisali.

(17) A okretanje trenda proizvodnje sa silazne na uzlaznu putanju sada je prioritet. 6

U navedenim je primjerima funkcija nezavisnih veznika ali i $a$ anaforična jer upućuju na sadržaj rečenice koja im je prethodila.

Iz iznesenih definicija kohezije te pregleda elemenata koji joj doprinose možemo zaključiti da je riječ o površinskoj strukturi teksta, odnosno da počiva na gramatičkim ovisnostima te da su, u skladu s tim, kohezivna sredstva eksplicitna.

\subsection{Koherencija}

Za razliku od kohezije koja počiva na gramatičkim ovisnostima te se, kao što je protumačeno u prethodnom poglavlju, odnosi na sastavnice površinske strukture teksta (na riječi koje vidimo i čujemo), svojstvo se koherencije prepoznaje u povezanosti među rečenicama unutar teksta, a koje je rezultat kognitivnih procesa, odnosno mentalnih aktivnosti (su)govornika (Badurina 2011). Koherentan tekst odlikuje dobra organizacija, logičan slijed rečenica i progresija teme (Watson Todd i dr. 2004). Već je iz tih nekoliko određenja razvidno da se koherencija tiče logičko-semantičkih veza među rečenicama/iskazima koje prepoznaju sudionici komunikacijskoga procesa pa se $s$ toga stajališta može odrediti kao subjektivna pojava čije tumačenje može ovisiti o interpretaciji recipijenta teksta. Takvom poimanju koherencije priklanja se i Hobbs (1979), koji kaže da je ona motivirana ponajprije govornikovom potrebom da ga sugovornik razumije. Da bi dokučio smisao teksta, njegov će se recipijent nužno morati oslanjati na vlastita iskustva s određenim tipom teksta, ali i na činjenice koje donosi kontekst. Smisao teksta tako izrasta iz veza između tekstualnoga i izvantekstualnoga svijeta. Iz svega dosad navedenog o koherenciji nameću se dva zaključka: prvi je da u njezino tumačenje moramo uvesti recipijenta poruke/teksta, a drugi da koherencija teksta nije (objektivno) mjerljiva onako kako se to u literaturi često tvrdi. Yule (1996) u tumačenju koherencije odlazi

6 Ova rečenica nije primjer isključivo anafore. U televizijskom diskursu, u govoru voditelja, naprimjer, ona se može pojaviti da bi se načinio prijelaz na novu vijest (obavijest). Dakle, služi kao signal za uvođenje novoga sadržaja, novoga dijela teksta, pa čak i novoga teksta. 
i korak dalje te tvrdi da ona počiva na tome kako recipijenti interpretiraju tekst, prije nego na tekstu samom čime »odgovornost « za razumijevanje teksta gotovo u potpunosti "prebacuje« na recipijenta. Isto tvrde i Sanders i Pander Maat (2006). Dakle, koherencija je manje »opipljiv« način povezivanja teksta (u odnosu na koheziju), onaj koji nije otvoren i eksplicitan. Spomenuti se autori takvim tumačenjem koherencije približavaju psiholingvističkom pristupu toj temi, odnosno stajalištu da se koherencija događa u recipijentovu umu te ovisi o njegovoj sposobnosti da razumije poruku koju je stvaratelj teksta želio prenijeti. Sanford (2006) tvrdi da koherenciji pridonose dva različita izvora informacija u tekstu: jezične informacije (engl. text cues) koje su u tekstu, poput kohezivnih markera, te proces mišljenja ili inferencija kod recipijenta teksta (engl. psychological constrains), kojima recipijent upotpunjuje informacije koje su eksplicitno dane u tekstu. Iz svega navedenog, sa psiholingvističkoga bi stajališta koherencija bila uspostavljanje veza između onoga što je spomenuto u tekstu i znanja o svijetu koje pomaže u interpretaciji. Odgovarajući na pitanje kako recipijent može procesuirati informacije koje se pojavljuju u tekstu Brown i Yule (1983) nude dva modela koji su također bliski psiholingvističkom tumačenju koherencije: prvi je model bottom-up, koji podrazumijeva formiranje značenja cjeline s pomoću značenja manjih jedinica (riječi i rečenica), a drugi razumijevanje teksta temelji na znanju o svijetu i kontekstu te ga autori nazivaju top-down strukturom.

Na granicu između opisanoga psiholingvističkog te primijenjenolingvističkoga tumačenja koherencije možemo smjestiti stavove Elisabeth Le (2004), koja također tvrdi da je konstrukcija koherencije psihološki proces utemeljen na vezama značenja pojedinih rečenica s temeljnim jezičnim znanjem te znanjem o svijetu. To rezultira tekstom, odnosno razumijevanjem teksta kao jedne značenjske jedinice. Međutim, Le (2004) naglašava da koherencija nije važna samo za razumijevanje teksta/diskursa, nego i za njegovu produkciju te tako, za razliku od svih dosad navedenih autora i definicija, fokus stavlja i na autora, a ne isključivo na recipijenta. Ona tvrdi da u procesu razumijevanja recipijenti (re)konstruiraju koherenciju teksta, ali pritom recipijentova koherencija ne mora nužno biti i autorova koherencija. Ipak, potpuno razumijevanje teksta pretpostavlja da recipijent može rekonstruirati autorovu koherenciju. ${ }^{7}$

Iz pregleda određenja koherencije može se zaključiti da se ona najčešće određuje kao subjektivna, manje »opipljiva « te ovisna i o recipijentovu jezičnom znanju i o znanju o svijetu. Budući da je iz određenja i kohezije i koherencije razvidno da doprinose povezivanju jedinica nižih redova u veću cjelinu (tekst/diskurs), u idućem poglavlju propitat ćemo jesu li koherencija kao »unutarnja«, implicitna struktura i kohezija kao eksplicitna struktura povezane te uvjetuju li jedna drugu.

7 To je iznimno važno u prevođenju, pri čemu je zadatak prevoditelja da prenese autorovu koherenciju u novi jezik. U tom kontekstu Le (2004) koherenciju ističe kao ključnu u procesu prevođenja. 


\subsection{Kohezija i koherencija - rasprava}

Možemo, vođeni de Beaugrandeom i Dresslerom (1981: 95), raspravu o vezi kohezije i koherencije započeti njihovom tvrdnjom da kohezija počiva na pretpostavci postojanja temeljne koherencije. Badurina (2011) navodi da koherentnosti teksta umnogome doprinosi njegova kohezivnost, odnosno u tekstu zastupljena i prepoznata kohezivna sredstva. Na tu su međuovisnost uputili i drugi autori. Halliday i Hasan (1976) tvrde da kohezija igra važnu ulogu u stvaranju koherentnoga teksta. S druge strane, Granger i Tyson (1996) tvrde da veza, odnosno uvjetovanost kohezije koherencijom ili obrnuto nije utvrđena. U nastavku ćemo ovoga rada stoga donijeti pregled teorija koje su se bavile vezom kohezije i koherencije te na koncu, na temelju vlastita istraživanja kohezije i koherencije teksta, iznijeti svoje rezultate i zaključke.

Teorije koje su se bavile odnosom kohezije i koherencije mogu se podijeliti na one u okviru kojih je uočeno postojanje veze između tih dviju sastavnica tekstne strukture te one koje tvrde da te veze nema. Među potonjima ističu se stajališta već spomenutih autorica Granger i Tyson (1996) koje tvrde da savršena kohezija nije jamstvo koherentnoga teksta. Ipak, napominju da će dobro poznavanje, odnosno pravilna upotreba kohezivnih sredstava svakako doprinijeti jasnijem izražavanju. S druge strane, Yeh (2004) upućuje na to da čak i kad tekst nema eksplicitne jezične kohezivne veze, recipijenti teksta rekonstruirat će smisao na temelju konteksta, odnosno vlastita znanja o svijetu. Carrell (1982) slično tvrdi da kohezija kao površinska tekstna struktura nije uzrok koherencije, nego njezina posljedica, a tu tvrdnju temelji na tumačenju ovih rečenica: Izlet je propao. Nitko se nije sjetio ponijeti vadičep. Dakle, izlet i vadičep nisu u leksičkoj kohezivnoj vezi, nego je za njihovo povezivanje nužno aktiviranje sheme izleta, odnosno aktiviranje recipijentova znanja o svijetu. Dakle, kohezivno je povezivanje izleta i vadičepa učinak, odnosno posljedica koherentnoga recipijentova tumačenja tih rečenica, a ne njegov uzrok.

S druge strane, mnogo su brojniji autori koji su uočili postojanje veze između kohezije i koherencije teksta. Halliday i Hasan (1976) definirali su koheziju kao odnos između dvaju tekstualnih elemenata u kojem jedan interpretira drugi. To je vrlo jasno vidljivo na primjeru He said so. u kojemu he i so pretpostavljaju nešto što je rečeno prije. Ne možemo interpretirati tu rečenicu, a da he i so ne povežemo s riječima iz prethodnih rečenica. Takvim se povezivanjem prema Hallidayu i Hasan stvara kohezivna veza, a one su dio onoga što stvara koherentni tekst. ${ }^{8}$ Dakle, autori koheziju smatraju temeljem koherencije. Hasan (1984) je dodatno naglasila vezu između kohezije i koherencije objašnjavajući da što je veći broj kohezivnih veza unutar teksta, to će tekst biti koherentniji. Palmer (1999) također ustvrđuje povezanost i uvjetovanost kohezije i koherencije tumačeći koheziju kao način na koji se »unutarnja« koherentnost pojavljuje u tekstu - lingvističkim sredstvima. Koherenciju, 
dakle, tumači kao tekstualni proizvod, rezultat različitih kognitivnih i metakognitivnih procesa koji počivaju na kohezivnim vezama. Slično tvrde i Brugman i Macaulay (2009), koje terminima kohezija i kohezivne veze podrazumijevaju lokalne veze među elementima u tekstu. Koherenciju tumače kao aspekt slušateljeva konceptualnog poimanja teksta kao cjeline, što se stvara upravo na temelju kohezivnih veza. Dakle, što je više kohezivnih veza, jača će biti i koherencija. U kroatistici nema mnogo istraživanja kohezije i koherencije, a neka su provele Bagarić Medve i Pavičić Takač (2013) te su također ustvrdile da upotreba odgovarajućih leksičkih i gramatičkih kohezivnih sredstava doprinosi koherenciji teksta.

\subsection{Primjer istraživanja kohezije i koherencije u tekstovima inojezičnih govornika hrvatskoga}

Od 2017. na Filozofskom fakultetu u Osijeku provodi se projekt Hrvatske zaklade za znanost »Koherencija pisanoga teksta u inome jeziku: hrvatski, njemački, engleski, francuski i mađarski jezik u usporedbi«, nositeljice Vesne Bagarić Medve. Da bi se analizirala obilježja koherentnosti teksta inojezičnih govornika hrvatskoga, kao i čimbenici koji utječu na (ne)koherentnost teksta u inome jeziku, u okviru projekta razvijen je zadatak pisane produkcije. Od ispitanika se tražilo da na zadanu temu napišu sastavak u kojemu će kritički pristupiti temi, izraziti svoje mišljenje te ga obrazložiti. Sastavak je trebao sadržavati od 150 do 180 riječi, a zadana tema bila je život u gradu. Istraživanje je provedeno od prosinca 2017. do ožujka 2019. Uz sastavak te informirani pristanak, studenti su zamoljeni da ispune i upitnik $u$ kojem su naveli osobne podatke (dob, spol, studij) te informacije o svom materinskom jeziku, trajanju učenja hrvatskoga jezika, boravku u Republici Hrvatskoj, a zamoljeni su i da na različitim razinama govorne i pisane produkcije ocjenama od 1 (vrlo niska razina) do 5 (vrlo visoka razina) procijene razinu svojih znanja i vještina u hrvatskom jeziku. Korpus za istraživanje kohezije i koherencije u inojezičnih govornika hrvatskoga čini 67 sastavaka koje je napisalo 67 ispitanika. Svim ispitanicima znanje hrvatskoga procijenjeno je na B1 razinu prema ZEROJ-u. Svi su ispitanici studenti i to: jugoistočnih studija, prava, političkih znanosti, povijesti, ekonomije i filoloških studija. Cilj je istraživanja, među ostalim, analizirati povezanost uporabe kohezivnih sredstava i razine koherentnosti teksta u inome jeziku, odnosno ispitati uporabu i raspon kohezivnih sredstava te organizaciju sadržaja, rečenica i slijeda misli u tekstu. Svi su nabrojani aspekti analizirani, odnosno procijenjeni prema standardiziranim opisivačima, razvijenima također u okviru projekta, pri čemu su za svaki od nabrojanih aspekata sastavaka ispitanicima dodjeljivane ocjene 0 (nije u skladu s opisivačem), 1 (vrlo slabo u skladu s opisivačem), 2 (slabo u skladu s opisivačem), 3 (djelomično u skladu s opisivačem), 4 (uglavnom u skladu s opisivačem) i 5 (u potpunosti u skladu s opisivačem). Sve tekstove procijenila su dva lektora hrvatskoga jezika.

Kriterij kohezije provjeravao se sljedećim pitanjima: kako ispitanici rabe kohezivna sredstva u tekstu i kakav je raspon upotrijebljenih kohezivnih sredstava? Taj 
kriterij opisan je dvama opisivačima: uporaba kohezivnih sredstava za povezivanje odlomaka i rečenica prikladna je i učinkovita te je raspon prikladno upotrijebljenih kohezivnih sredstava širok za zadatak. Pri procjeni prema prvom opisivaču pozornost je dakle posvećena prikladnoj i funkcionalnoj upotrebi kohezivnih sredstava, kao što su osobne zamjenice, zavisnosloženi veznici i slično, dok je kod drugoga opisivača naglasak stavljen na raznovrsnost upotrijebljenih kohezivnih sredstava.

$\mathrm{U}$ analiziranim sastavcima uočena je pretjerana uporaba jednoga kohezivnog sredstva. Riječ je o vezniku $i$, kao u sljedećim rečenicama:

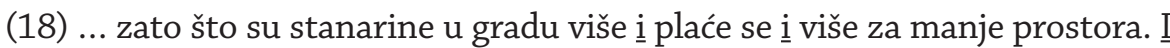
dobra infrastruktura nema samo prednosti. (...) I puno ljudi produciraju i puno smeća.

U jednoga ispitanika veznik koji se učestalo ponavlja jest ali, a zabilježena je i njegova pogrešna uporaba:

(19) Ali zašto oni ovo radi? (...) Ali život u gradu ima takođe nedostatki... Ali najviša problema... (...) Na selu ali ima vrlo mnogo posla, ... (...) Ali se ne može baviti svaki dan...

Ukupno gledano, ispitanici su ipak vrlo dobro ocijenjeni kada je riječ o koheziji. Prosječna je ocjena prvoga opisivača - prikladna i učinkovita uporaba kohezivnih sredstava - 4,4, dok je drugi opisivač - širok raspon kohezivnih sredstava - ocijenjen ukupnom prosječnom ocjenom 4,3. Iz brojki se može zaključiti da većina ispitanika ipak dobro vlada uporabom kohezivnih sredstava s obzirom na procijenjenu jezičnu razinu.

Kriterij koherencije određen je u odnosu na sljedeće pitanje: kako je organiziran sadržaj teksta i je li slijed misli i rečenica logičan? Pri procjeni teksta prema prvom opisivaču - logična organizacija sadržaja i rečenica - promatrano je je li sadržaj na razini cijeloga teksta organiziran na logičan način, odnosno pozornost je posvećena globalnoj koherenciji. Prosječna je ocjena za taj opisivač vrlo visoka - 4,5. To znači da su ispitanici sadržaj na razini cijeloga teksta u potpunosti organizirali na logičan način, da se pojedini dijelovi teksta (uvod, razrada, zaključak) logično nadovezuju jedan na drugi te da svi dijelovi sadrže ono što se od njih očekuje, naprimjer da se u uvodu ne daje mišljenje, da se u razradi ne miješa zaključak s argumentima ili da se u razradi ne govori istovremeno i zbunjujuće o prednostima i nedostacima u odnosu na zadanu temu. Na taj se opisivač nadovezuje i drugi, koji se odnosi na razumljiv slijed misli i rečenica koji je također ocijenjen ocjenom 4,5. Pri tom je opisivaču posebna pozornost stavljena na lokalnu koherenciju, odnosno promatralo se u kojoj mjeri misli i rečenice imaju logičan slijed, čita li se tekst lako, proizlazi li sadržaj rečenice iz sadržaja prethodne ili iz sadržaja prethodnoga konteksta (ne previše udaljenoga), a pratilo se i povezivanje rečenica između odlomaka.

Sa stajališta teorijskoga pristupa koheziji i koherenciji koji je iznesen u uvodnim poglavljima ovoga rada, ovo je ukratko predstavljeno istraživanje potvrdilo 
saznanja koja o tim dvama konceptima postoje. Naime, kohezija se odnosi na površinsku (gramatičku, leksičku, pravopisnu) strukturu pisanoga teksta, a koherencija na povezanost među rečenicama unutar teksta, a koja je rezultat kognitivnih procesa, odnosno govornikovih/ispitanikovih mentalnih aktivnosti. Ovo je istraživanje još jednom potvrdilo da su kohezija i koherencija povezane te da uvjetuju jedna drugu. Naime, prosječne ocjene kohezije i koherencije u ispitanika gotovo su jednake - kohezija je ocijenjena prosječnom ocjenom 4,4, a koherencija prosječnom ocjenom 4,5, odnosno sastavci koji imaju dobro ocijenjenu koheziju, imaju dobro ocijenjenu i koherenciju. Isto tako, lošije ocjene kohezije podudaraju se s lošijim ocjenama koherencije u nekih ispitanika. Nije zabilježen nijedan slučaj u kojemu bi kohezija bila ocijenjena iznimno dobro, a koherencija loše i obrnuto. Ipak, naše zaključke, utemeljene trenutačno isključivo na istraživanju kohezije i koherencije teksta inojezičnih govornika hrvatskoga, iznosimo s oprezom. Oni će dobiti svoju punu vrijednost tek kada se usporede s rezultatima istraživanja kohezije i koherencije u tekstovima izvornih govornika.

Na temelju teorijskoga pregleda, ali i vlastita istraživanja, možemo ustvrditi da su kohezija i koherencija kao sastavnice tekstne strukture povezane te da uvjetuju jedna drugu. Primjeri koherentnih rečenica među kojima se ne prepoznaju nikakve kohezivne »eksplicitne« veze, poput onih koje donose Widdowson i Carrell, po našem mišljenju nisu dokaz da kohezija i koherencija nisu povezane. Smatramo da su one samo dokaz da je riječ o složenim konceptima uvjetovanima upotrebom jezičnih - leksičkih i gramatičkih - elemenata, recipijentovom koherencijom, koja je istovjetna autorovoj (ili bi tako bar trebalo biti!) te izvanjezičnim, pragmatičkim znanjem, odnosno znanjem o svijetu. Tek uzimanjem svih tih sastavnica u obzir pri tumačenju kohezije i koherencije teksta, može ih se pravilno protumačiti, kao pojedinačne i kao međusobno uvjetovane koncepte.

\section{Zaključak}

Cilj je ovoga rada bio istražiti i donijeti pregled dijela teorijskih pristupa koji su se bavili tekstom, odnosno sastavnicama diskursne kompetencije - elementima koji tekst čine tekstom - kohezijom i koherencijom. Na temelju pregleda u ovome radu, može se ustvrditi da su stavovi o tim dvama konceptima prilično neujednačeni te se kreću od njihova gotovo potpunoga izjednačavanja - kao što to čini, naprimjer, Glovacki-Bernardi (2004), tumačeći i koherentnost potpuno gramatičkipreko onih autora koji su ih postavljali u odnose (među)uvjetovanja (npr. Badurina 2007, 2011, 2016; Carrell 1982; Watson Todd i dr. 2004) do onih koji smatraju da kohezija i koherencija ne uvjetuju jedna drugu te da nisu ni u kakvoj vezi (npr. Granger, Tyson 1996). Ipak, neke se odrednice sa sigurnošću mogu pripisati tim dvama složenim konceptima. Kohezija se tako odnosi na površinsku strukturu teksta, a istražujući je zapravo istražujemo na koji način jezične jedinice omogućuju da tekst funkcionira kao jedna značenjska cjelina, odnosno koje su to jezične jedinice. S dru- 
ge strane, koherencija je manje "vidljiva«, odnosi se na psihološki proces utemeljen na vezama značenja pojedinih rečenica s temeljnim jezičnim znanjem te znanjem o svijetu te se, dakle, za njezino tumačenje obavezno u obzir uzima i recipijent teksta, a ne samo njegov autor. Na temelju vlastita istraživanja kohezije i koherencije teksta inojezičnih govornika hrvatskoga zaključujemo da su ta dva koncepta ipak povezana te da bolja kohezija teksta doprinosi i njegovoj boljoj koherentnosti. Primjere autora koji su imali suprotne stavove ne smatramo argumentima protiv našega zaključka, nego samo dokazima da je doista riječ o složenim konceptima pri čijem se tumačenju moraju uzeti u obzir i tekst na svim razinama (gramatičkoj, leksičkoj, semantičkoj), ali i autor i recipijent teksta sa svojim jezičnim i izvanjezičnim znanjem.

U odnosu na opisano istraživanje kohezije i koherencije teksta u inojezičnih govornika hrvatskoga, idući je korak usporedba tekstova izvornih i inojezičnih govornika kako bi se utvrdilo razlikuju li se tekstovi u smislu kohezije i koherencije, odnosno rabe li ista kohezivna sredstva, je li uporaba nekih kohezivnih sredstava rezultat interferencije s materinskim jezikom, naziru li se kada je riječ o koherenciji teksta kulturološke razlike u smislu referiranja na neka opća mjesta u određenoj kulturi koja možda nisu poznata drugoj jezičnoj zajednici i slično. Tek usporedbom rezultata dobit ćemo potpuni uvid u problematiku odnosa kohezije i koherencije.

$\mathrm{Na}$ koncu, istraživanja kohezije i koherencije teksta čiji smo pregled donijeli u ovome radu ne bi trebala biti sama sebi svrhom, nego bi ih trebalo uzimati u obzir pri oblikovanju didaktičkih i glotodidaktičkih materijala koji bi bili izrazito korisni za pisanje tekstova na stranome, ali i na materinskom jeziku.

\section{Literatura}

Anić, Vladimir (1998). Rječnik hrvatskogajezika. Zagreb: Novi liber

Anić, Vladimir, Klaić, Nikola, Domović, Želimir (2002). Rječnik stranih riječi. Zagreb: Saniplus

Bachman, Lyle F. (1990). Fundamental Considerations in Language Testing. Oxford: Oxford University Press

Bachman, Lyle F., Palmer, Adrian S. (1996). Language Testingin Practice:Designing and Developing Useful Language Tests. Oxford: Oxford University Press

Bachman, Lyle F., Palmer, Adrian S. (2010). Language Assessment in Practice. Oxford: Oxford University Press

Badurina, Lada (2007). Od sintakse prema suprasintaksi - dvosmjerno. Kuna, Branko, ur. Sintaktičke kategorije. Osijek: Filozofski fakultet, 9-21

Badurina, Lada (2011). Od sintakse prema suprasintaski i dalje. Mićanović, Krešimir, ur. Sintaksa hrvatskoga jezika - Književnost i kultura osamdesetih. Zbornik radova 39. seminara Zagrebačke slavističke škole. Zagreb: Zagrebačka slavistička škola, 43-65

Badurina, Lada (2016). Jezikoslovni pristupi tekstu. Croatica XL, 60: 49-61 
Bagarić Medve, Vesna, Pavičić Takač, Višnja (2013). The Influence of Cohesion and Coherence on Text Quality: A Cross-Linguistic Study of Foreign Language Learners' Written Production. Piechurska-Kuciel, Ewa i Szymanska-Czaplak, Elzbieta, ur. Lagnuage in Cognition and Affect. Berlin: Springer, 111-131

Beaugrande, Robert de, Dressler, Wolfgang (1981). Introduction to text linguistics. London, New York: Longman

Brown, Gillian, Yule, George (1983). Discourse Analysis. Cambridge: Cambridge University Press

Brugman, Claudia, Macaulay, Monica (2009). Relevance, cohesion, and storyline: The discourse funcion of the Karuk particle káruma. Journal od Pragmatics 41: 1189-1208

Canale, Michael (1983). From communicative competence to communicative language pedagogy. Richards, Jack C., Schmidt, Richard W., ur. Language and Communication, 2-27

Carrell, Patricia L. (1982). Cohesion is not coherence. TESOL Quarterly 16, 4: 479-488

Celce-Murcia, Marianne (2007). Rethinking the role of communicative competence in language teaching. Alcón Soler, E., Safont Jordá, M. P., ur. Intercultural Language Use and Language Teaching, 41-57

Glovacki-Bernardi, Zrinjka (2004). O tekstu. Zagreb: Školska knjiga

Granger, Sylviane, Tyson, Stephanie (1996). Connector usage in the English essay writing of native and non-native EFL speakers of English. World Englishers 15, 1: 17-27

Halliday, Michael A. K. (1975). Learning how to Mean (Explorations in the Development of Language). London: Edward Arnold

Halliday, Michael A. K., Hasan, Ruquaya R. (1976). Cohesion in English. London: Longman

Hasan, Ruquaya R. (1984) Coherence and Cohesive Harmony. Flood, J., ur. Understanding Reading Comprehension. Delaware: International Reading Association, 181-219

He, Agnes Weiyun (2001). Discourse Analysis. Aronoff, M., Miller, J. R., ur. The Handbook of Linguistics. Oxford: Blackwell, 428-445

Hobbs, Jerry R. (1979). Coherence and Coreference. Cognitive science 3: 67-90

Hymes, Dell H. (1972). On communicative competence. Pride, John B., Holmes, Janet, ur. Sociolinguistics, 269-293

Kuna, Branko (2008). O antecedentu povratno-posvojne zamjenice svoj u hrvatskom jeziku. Slavica Wratislaviensia 6: 199-207

Le, Elisabeth (2004). The role of paragraphs in the construction of coherence - text linguistics and translation studies. IRAL 42: 259-275

McHoul, Alec (1994). Discourse. Asher, R. E., ur. The Encyclopedia of language and linguistics 2. Oxford, New York, Seoul, Tokio, 940-949

Mihaljević, Milan (1998). Generativna sintaksa i semantika. Zagreb: Hrvatsko filološko društvo

Palmer, Juan Carlos (1999). Coherence and Cohesion in the English Language Classroom: the Use of Lexical Reiteration and Pronominalisation. RELC Journal 30, 2: 61-85

Pavičić Takač, Višnja, Bagarić Medve, Vesna (2013). Jezična i strategijska kompetencija u stranome jeziku. Osijek: Filozofski fakultet

Pavlou, Pavlos (1994). The Role of Cohesion in Communicative Competence as Exemplified in Oral Proficiency Testing. https://files.eric.ed.gov/fulltext/ED369258.pdf, 2. srpnja 2019. 
Sanders, Ted, Pander Maat, H. (2006). Cohesion and Coherence: Linguistic Approaches. Brown, Keith, ur. Encyclopedia of Language and Linguistics. London: Elsevier, svezak 2, 591-595

Sanford, Anthony (2006). Coherence: Psycholinguistic Approach. Brown, Keith, ur. Encyclopedia of Language and Linguistics. London: Elsevier, svezak 2, 585-591

Savignon, Sandra J. (1983). Communicative Competence: Theory and Classroom Practice. Texts and Contexts in Second Language Learning. Massachusetts: Addison-Wesley Publishing Company

Silić, Josip (1984). Od rečenice do teksta. Zagreb: Sveučilišna naklada Liber

Silić, Josip, Pranjković, Ivo (2005). Gramatika hrvatskoga jezika. Zagreb: Školska knjiga

Van Dijk, Teun. A. (1997). The Study of Discourse. van Dijk, Teun A., ur. Discourse as Structure and Prosess. London, 1-34

Velčić, Mirna (1987). Uvod u lingvistiku teksta. Zagreb: Školska knjiga

Watson Todd, Richard, Thienpermpool, Patteera, Keyuravong, Sonthida (2004). Measuring the coherence of writing using topic-based analysis. Assessing Writing 9: 85-104

Widdowson, Henry George (1978). Teaching Language as Communication. Oxford: Oxford University Press

Yeh, Chun-Chun (2004). The Relationship of Cohesion and Coherence: A Contrastive Study of English and Chinese. Journal of Language and Linguistics 3, 2: 243-260

Yule, George (1996). The Study of Language. Cambridge: Cambridge University Press

Zajednički europski referentni okvir za jezike: učenje, poučavanje, vrednovanje (2005). Zagreb: Školska knjiga

Žic Fuchs, Milena (1991). Znanje o jezikui znanje o svijetu: semantička analiza glagola kretanja u engleskom jeziku. Zagreb: Filozofski fakultet

\section{On cohesion and coherence of text}

The present paper provides a brief overview of theories focusing on text, with special emphasis on the terms cohesion and coherence. As a display of the communicative nature of language, the notion of text has in linguistic history often eluded grammatical description. Mid-20th century saw a significant change in this respect, with the emergence of Actual Syntax, Systemic Functional Theory and M. A. K Halliday's Functional Grammar and Text Linguistics. These theories caused significant changes in perspectives towards grammar, whose direction tends to turn from text towards the sentence. The focus shift of grammatical description towards functional linguistic units implied a more intense interest in (linguistic) competence, which is roughly classified into grammatical and pragmatic competence, i.e. to the ability of efficient use of grammatical knowledge. Cohesion - the presence of direct linguistic relations that create text structure, and coherence - the degree of text intelligibility, form an important aspect of efficient language use in all theoretical approaches. This paper, therefore, aims to examine and provide an overview of a fraction of theoretical approaches that have tackled these two complex concepts, particularly given the lack of their systematic description in the studies of Croatian.

Ključne riječi: tekst, diskurs, diskursna kompetencija, kohezija teksta, koherencija teksta

Keywords: discourse, linguistic competence, discourse competence, cohesion, coherence 